\title{
Social Correlates of Deviant Behavior among Teachers in Public Secondary Schools in Nairobi County, Kenya
}

\author{
Magdalene Mwele ${ }^{1}$, Virginia Nyagah $(\mathrm{PhD})^{2}$, Simon Kangethe $(\mathrm{PhD})^{3}$ \\ ${ }^{1,2}$ Department of Psychology, The Catholic University of Eastern Africa \\ ${ }^{3} \mathrm{KCA}$ University
}

\begin{abstract}
Globally, deviant behavior is found to be a social challenge which has created different problems in the present society. With respect to school setting, the behavioral deviancy of teachers has attracted considerable attention of researchers and educationalists. This study therefore assessed demographic correlates of deviant behavior among teachers in public secondary schools in Nairobi County, Kenya. The study was guided by Self-determination theory and Transactional Models. The survey research design was adopted for the study. The target population was 2387 comprising of 2291 teachers. A total sample of 385 participants were selected using simple random sampling technique. Data were collected using modified workplace deviance scale and social correlates questionnaire. Data was analyzed using univariate analysis, and Pearson correlation analysis. From the findings teachers deviance had the highest on the sabotage domain (mean=3.0429; $\mathrm{SD}=1.09429$ ) while the subscale of gossip had the lowest mean (mean=2.9898; $\mathrm{SD}=1.13283$ ).On social correlates, workload had the greatest contribution to deviant behavior ( mean=2.3507; $\mathrm{SD}=.86610$ ) while responsibility had the lowest contribution to deviant behavior (mean=2.0442; SD=.73774). The findings indicate that teachers' workload had high impact on their deviance behavior. This implies that education stake holders ought to engage teachers on the area of workload in order to define the appropriate optimum work that teachers should hold. This will help in reducing deviance and improving productivity.
\end{abstract}

Key words: Teacher deviance, Social correlates, sabotage, workload

\section{INTRODUCTION}

$\mathrm{D}$ eviance in learning institutions remains an important issue to educationists and other scholars globally. This phenomenon has been widely researched but most of the studies are skewed towards learners. However teacher deviance research is gaining momentum as an area of interest for many researchers. For instance, Khan (2017) study on teachers' deviant in the University of Peshawar found that level of teachers' deviant behavior was above average. The study indicated that teachers showed favoritism, wasted time during teaching, took longer breaks, used verbal abuse, did not follow the course content as well as provoking students' against other teachers.

A study by Ünal (2012) in Konya province Turkey found that teachers repeated 24 types of deviant behavior for a total of
131 incidents. Further, the study found that nearly all the deviant behavior of teachers had a significant impact in flaunting rules or affecting interpersonal relationships within schools. However, Aksu (2016) found that teachers in Anatolian High Schools in İzmir displayed low level organizational deviant behavior. Similarly, Köse (2013) study which investigated middle school teachers' perception of deviant behavior and its relation to administrators' strategic leadership skills found that teachers' perceptions of deviance in their schools were at "seldom" level.

Deviant behavior among teachers is not only a global problem but has also been reported in Africa. For instance, Uwannah (2015) found that there is a continuous wide spread news that the menace of deviant behavior among the university lecturers such as theft, absenteeism, aggression, verbal abuse, spreading rumors, sexual harassment among others in Arica. Further, Igbe Okpa and Aniah (2017) study found that deviant behavior among university staff was on high level. Some of the deviant behavior identified in the study were irregularity in conducting examination for students, abuse of office, distortion of staff records and students' grades for financial gain, gross insubordination or disregard for constituted authority, employment racketeering, misappropriation of university funds, admission fraud and impersonation.

Different factors have been associated with deviance behavior among teachers and educationists. For instance, Bhui, Dinos, Galant-Miecznikowska, de Jongh and Stansfeld (2016) found that personality characteristics, modelling others behavior, lack of control of feelings of anger, frustrations and dissatisfaction were major actors that influenced deviance among teachers. In addition, Lawrence and Robinson (2007) stated that if teachers do not receive the expected attention, respect and were not fairly treated in the institutions, they would show deviant behavior in the institution.

Salakhova, Bulgakov, Sokolovskaya, Khammatova and Mikhaylovsky, (2016) in their study in Russia on substantive characteristics of deviant behavior as a social and psychological phenomenon found out that psychosocial factors such as interactions between the personality and society results in deviant behavior. They also noted that the position of the personality within the group dynamic and in 
this case, the teacher's ways of communication and interactions within the school community may result to deviant behavior.

A study by Fagbenro and Olasupo (2020) on quality of family life and workplace deviant behavior with perceived competence as a mediator among university staff found out that there was a negative relationship between quality of life and workplace deviant behavior. The results also showed there is negative association between family conflict and deviance. The results showed that work-life balance, except personal commitment, has a significance influence on deviant workplace behavior. They also found that when employees are happy at home there is a positive behavior at the work place because employees have a fall back when faced with challenges at work.

Studies carried out in Kenya have not established manifestation of deviant behavior among teachers but rather have differently looked at sources of stress and coping strategies among teachers (Kagwe, Ngigi \& Mutisya, 2018). The stress could hence result to a deviant behavior. On the other hand, Kagwe et. al. (2018) found out that in the last two decades teaching has emerged to be the most stressful profession. They also found that the working conditions, living conditions and lack of resources were the main source of stress among teachers which may result in deviant behavior. When an organization has rigid rules, employees are emotionally exhausted stress may crop up results to negative deviant behavior. Deviant behavior is destructive to the institution performance and personal service delivery.

Muiga, Ombui and Iravo (2016) noted that teachers' relationship with the school leaders had deterioration in interpersonal relations, laxity in student discipline, falling sick with personal problems often, over sensitivity and personalization of criticism resulting in interpersonal deviance behavior. The teachers may also divert their concentration from class to money making ventures or career pursuits at the expense of their job. This may have led to constant requests for transfers, giving nothing extra apart from routine attendance of class. They often manifest of feelings with anger, irritability, frustration, disillusionment and low morale. The question that needed to be addressed is what could have driven once enthusiastic, energetic, self-driven and selfmotivated teachers to such depths of despair. The question is hardly addressed by the teacher himself and the education managers. Ndung'u (2017) found out that many education managers impose disciplinary measures because of the deviance behavior portrayed by the teachers even without investigating why the teacher could be manifesting such behavior and may be looking for a way of addressing them first.

The organizational deviance being witnesses in the teaching fraternity is as a result of teachers feeling like teaching is being done mechanically, routinely and in a detachable manner driven by the instinct of survival. The lack of excitement is evidenced through, absenteeism, non- punctuality for school activities, sluggishness in performance of duty, employment of time-wasting techniques, disregard for authority and failure to meet deadlines is a result of organizational deviance behavior.

According to Ndung'u (2017) study, many education managers impose disciplinary measures because of the deviance behavior portrayed by the teachers even without investigating why the teacher could be manifesting such behavior and may be looking for a way of addressing them first. This means that the problem of deviance has not been resolved by the said reforms. Therefore, the current study, sought to fill in the gap by assessing psychosocial correlates of deviance behavior among teachers in public secondary schools.

In this context the term 'social' is used to denote a broad cluster of organizational factors that are not motivations to the nature of teaching, but rather dependent on the climate of the educational institution or the wider context of educational domain. Globally, social correlates to deviance have been researched. Howald, Lortie, Gallagher and Albert (2018) in a paper on preventing and deterring organization deviance, they established that social environments can influence teachers' behavior in many ways hence deviance behavior was as a result of these influences across all levels of the school organization. Teachers are also influenced by their colleagues and peers. This means the way other teachers behavior in a school will affect the teachers' deviance behavior.

Khan, Mahmood and Kanwal (2015) investigated the mediating role of perceived organizational support on relationship between perceived supervisor support and workplace deviance within a non-western context. Convenience sampling technique to obtain a sample size of 800 front-line employees working in the top banks of Pakistan. Workplace deviance was measured using WBD developed by Bennett and Robinson's (2000). Pearson correlation was applied to identify relationship among the variables. The study found that there exists a moderate negative relationship between workplace deviance and perceived organizational support (-0.374), as well as between workplace deviance and perceived supervisor support (0.368).Moreover, a strong and positive relationship between perceived organizational support and perceived supervisor support with the value of (0.797) was observed

Azim, Hassan, Zaid and Daud (2020) examined the Influence of Supervisor Support and Organizational Trust on Workplace Deviant Behavior. The sample size comprised of lecturers at seven Higher Learning Institutions around Klang Valley, Malaysia. Supervisor support was measured using three items adopted from the originalinstrument by Palomo, Beinart and Cooper (2010) while Workplace deviance behavior was measured using 7 items developed by Peterson (2002). The study found that supervisory support and organizational trust influence workplace deviant behavior. The study concluded that supervisory support and organizational trust increase 
psychological contracts and thus reduced the workplace deviant behavior among lecturers.

Teachers' promotion opportunities could also be a source of stress which could in turn lead to deviant behaviour. This was confirmed by a study Adeoti \& Shamsudin (2020) on the opportunity, job pressure and deviant workplace behaviour a case of does neutralization mediate the relationship? A study of faculty of members of public universities in Nigeria found out that there was need of the management to curb deviant behaviour among faculty members. This could be achieved through improved work environment and enhancing the ethical climate and institutional policies that may constitute some pressure on faculty members. The study also found that there were limited opportunities available for faculty members' promotion hence leading to employees' deviance behavior. The study recommended that there was need for implementation of policies that would help the institutions to promote ethical climate.

Travers and Cooper's (1997) study among teachers in Britain and France, workload and long working hours emerged as particular issues for English teachers as opposed to colleagues in France. The workplace deviant behavior was found to be related to stress factors at the work place. Fisher (2011) noted the British teachers who were involved in the researcher cited work overload, poor working conditions and meagre pay as some of the sources of stress which in turn resulted in deviant behavior among the teachers.

Another study by Igbe, Okpa and Aniah (2017) among 361 university employees on the working conditions and deviant behavior of employees in University of Calabar, Cross River State, Nigeria found out that there was a positive significant relationship between non-payment of allowances, poor worker safety and deviant behavior among employees. The lack of payment of allowance left employees with external economic pressure hence making the employees to engage in criminal tendencies such as corruption, huge debts and borrowing learner's money in exchange for exams. Deviant behavior was noted to be one of the human prevalent problems in organization.

The purpose of this study was therefore to examine the social correlates of teacher deviance in Nairobi County Kenya. This was to generate new knowledge that would lead to contextual understanding of deviance in Kenya.

\section{METHODOLOGY}

This study adopted the survey research design. This approach enables collection of large amounts of data from a large sample within a short period. The target population for this study was all public secondary schools in Nairobi County. There are 96 public secondary schools with a total population of 2291 teachers and 96 principals (County Director of Education, 2020). Therefore, the total target population for the study was 2387. In this study, the sample size was determined as proposed by Godden (2004) was adopted to determine the sample size for this study. The sample determination formula was

$$
n=\frac{z^{2} \times P(1-P)}{E^{2}}
$$

Where: $\mathrm{n}=$ Sample Size for infinite population

$Z=$ Confidence level at 95\% (Standard value 1.96)

$\mathrm{P}=$ Population proportion assumed to be $0.5(50 \%)$

$\mathrm{E}=$ Margin of Error at 5\% (0.05)

$$
\mathrm{n}=\frac{1.96 \times 0.5(1-0.5)}{0.05^{2}}
$$

Therefore, sample size for teachers was 385 .

\section{Research Instruments}

The study made use of questionnaires to collect data on Socio demographic variables and the main variables of the study.

\section{Modified Work Place Deviance Scale}

Respondents' level of deviance behavior was measured using modified work place deviance scale developed by Robins and Bennet (2000). The tool had 12 items Respondents were provided with statements on reactions portrayed by teachers in schools when interacting with other colleagues. They were asked to indicate how often these statements apply to them. They were given a 5- point Likert scale starting from not all (1), less often (2), moderate often (3), often (4) and very often (5). The items were put into 4 subscales: Absenteeism (items 1, 2 and 3), negligence (items 4, 5, and 6), sabotage (items 7, 8 and 9) and gossip (items 10, 11 and 12). During scoring, all the scores in each category were added and average means computed. The lowest possible mean was 1 while the highest possible mean was 5 . The scores were interpreted that if respondents scored below 2.5, it meat that their deviance behavior was low while if the respondents scored above 2.5 , it meant that their deviant behavior was high.

\section{Social Correlates Questionnaire}

Social correlates of deviant behavior among teachers was measured using a 15 item Likert questionnaire. Respondents were asked to read the provided statements and indicating how certain variables were likely to contribute to their own deviance. The questionnaire measured social correlates on six domains namely workload, responsibilities, leadership relations, administrative support, policies and physical facilities. During scoring, all items for each subscale were added with high scores indicating high deviance while low score indicating no deviance.

\section{RESULTS}

The study sought to understand social correlates of deviance behaviour among respondents as well as find the relationship between the two variables. 


\section{Social Correlates of Deviance Behaviors among Respondents}

The study sought to examine levels of social correlates of deviance behaviors among respondents. During scoring, all the scores in each category were added and means computed. The lowest possible mean for each subscale was 1 while the highest possible mean was 4 . The scores were interpreted that if respondents scored below 2.5 , it meant that the listed social correlates of deviance behavior was low among respondents while if the respondents scored above 2.5 , it meant that the listed social correlates of deviant behavior among respondents was high. The results of the respondents' descriptive statistics of social correlates of deviance behaviors among respondents were presented in Table 1.

Table 1: Social Correlates of Deviance among Teachers in Public Secondary Schools in Nairobi County

\begin{tabular}{|c|c|c|c|c|c|}
\hline \multicolumn{7}{|c|}{ Social Correlates } \\
\hline & $\mathrm{N}$ & Minimum & Maximum & Mean & $\begin{array}{c}\text { Std. } \\
\text { Deviation }\end{array}$ \\
\hline Workload & 326 & 1.00 & 4.00 & 2.3507 & .86610 \\
\hline Responsibility & 326 & 1.00 & 4.00 & 2.0442 & .73774 \\
\hline $\begin{array}{c}\text { Leadership } \\
\text { Relations }\end{array}$ & 326 & 1.00 & 4.00 & 2.0325 & .98546 \\
\hline $\begin{array}{c}\text { Administration } \\
\text { Support }\end{array}$ & 326 & 1.00 & 4.00 & 2.2193 & .86214 \\
\hline Policies & 326 & 1.00 & 4.00 & 2.1629 & .67473 \\
\hline $\begin{array}{c}\text { Physical } \\
\text { Facilities }\end{array}$ & 326 & 1.00 & 4.00 & 2.2863 & .93288 \\
\hline & & & & & \\
\hline
\end{tabular}

Findings in table 1 indicate how various social correlates contributed to deviant behavior among respondents. The results indicate that workload had the greatest contribution to deviant behavior (mean=2.3507; $\mathrm{SD}=.86610)$ while responsibility had the lowest contribution to deviant behavior (mean=2.0442; $\mathrm{SD}=.73774)$.

\section{Descriptive Statistics of Deviance Behavior among Teachers in Public Secondary Schools in Nairobi County}

The study sought to understand descriptive statistics of deviance behavior among teachers in public secondary schools. Respondents' level of deviance behavior was measured using modified work place deviance scale developed by Robins and Bennet (2000). Respondents were asked to indicate how often the statements in the tool apply to them. They were given a 5-point Likert scale starting from not all (1), less often (2), moderate often (3), often (4) and very often (5). The items were put into 4 subscales: Absenteeism (items 1, 2 and 3), negligence (items 4, 5, and 6), sabotage (items 7, 8 and 9) and gossip (items 10, 11 and 12). During scoring, all the scores in each category were added and average means computed. The lowest possible mean for each subscale was 1 while the highest possible mean was 5 . The results of the respondents' descriptive statistics of deviance behavior were presented in Table 2.

Table 2: Deviance Behavior among Teachers in Public Secondary Schools in Nairobi County

\begin{tabular}{|c|c|c|c|c|c|}
\hline \multicolumn{7}{|c|}{ Teacher Deviance } \\
\hline & $\mathrm{N}$ & Minimum & Maximum & Mean & $\begin{array}{c}\text { Std. } \\
\text { Deviation }\end{array}$ \\
\hline $\begin{array}{c}\text { Teacher } \\
\text { Absenteeism }\end{array}$ & 326 & 1.00 & 5.00 & 3.0429 & 1.09429 \\
\hline $\begin{array}{c}\text { Negligence } \\
\text { of Duties }\end{array}$ & 326 & 1.00 & 5.00 & 3.0102 & 1.09258 \\
\hline Sabotage & 326 & 1.00 & 5.00 & 3.0133 & 1.11623 \\
\hline Gossip & 326 & 1.00 & 5.00 & 2.9898 & 1.13283 \\
\hline & & & & & \\
\hline
\end{tabular}

Table 2 shows that the level of deviance behaviors among respondents who took part in the study was above average. Specifically, the subscale of teacher absenteeism had the highest mean (mean=3.0429; $\mathrm{SD}=1.09429)$ while the subscale of gossip had the lowest mean (mean=2.9898; $\mathrm{SD}=1.13283$ ).

Relationship between Social Correlates and Deviant Behavior among Teachers in Public Secondary Schools

The study sought to find out whether social correlates had had any relationship with deviant behavior among teachers in public secondary schools. Pearson correlation analysis was used to find this relationship and findings presented in table 39.

Table 3: Effects of Social Correlates on Deviant Behaviour among Teachers in Public Secondary Schools

\begin{tabular}{|c|c|c|c|c|c|c|c|c|c|c|c|}
\hline & & Workload & Responsibility & $\begin{array}{l}\text { Leadership } \\
\text { Relations }\end{array}$ & $\begin{array}{l}\text { Administration } \\
\text { Support }\end{array}$ & Policies & $\begin{array}{l}\text { Physical } \\
\text { Facilities }\end{array}$ & $\begin{array}{c}\text { Teacher } \\
\text { Absenteeism }\end{array}$ & $\begin{array}{c}\text { Negligence } \\
\text { of Duties }\end{array}$ & Sabotage & Gossip \\
\hline \multirow{3}{*}{$\begin{array}{c}\text { Teacher } \\
\text { Absenteeism }\end{array}$} & $\begin{array}{c}\text { Pearson } \\
\text { Correlation }\end{array}$ & -.040 & .049 & .090 & .012 & .009 & -.067 & 1 & & & \\
\hline & $\begin{array}{l}\text { Sig. (2- } \\
\text { tailed) }\end{array}$ & .474 & .382 & .106 & .833 & .874 & .230 & & & & \\
\hline & $\mathrm{N}$ & 326 & 326 & 326 & 326 & 326 & 326 & 326 & & & \\
\hline \multirow{3}{*}{$\begin{array}{l}\text { Negligence } \\
\text { of Duties }\end{array}$} & $\begin{array}{c}\text { Pearson } \\
\text { Correlation }\end{array}$ & -.020 & .072 & .097 & .025 & .041 & -.035 & $.921^{* *}$ & 1 & & \\
\hline & $\begin{array}{l}\text { Sig. (2- } \\
\text { tailed) }\end{array}$ & .713 & .194 & .079 & .648 & .461 & .528 & .000 & & & \\
\hline & $\mathrm{N}$ & 326 & 326 & 326 & 326 & 326 & 326 & 326 & 326 & & \\
\hline Sabotage & $\begin{array}{c}\text { Pearson } \\
\text { Correlation }\end{array}$ & -.042 & .044 & .076 & .015 & -.003 & -.060 & $.960^{* *}$ & $.937^{* *}$ & 1 & $.1^{* *}$ \\
\hline
\end{tabular}


International Journal of Research and Innovation in Social Science (IJRISS) |Volume VI, Issue I, January 2022 |ISSN 2454-6186

\begin{tabular}{|c|c|c|c|c|c|c|c|c|c|c|c|}
\hline & $\begin{array}{l}\text { Sig. (2- } \\
\text { tailed) }\end{array}$ & .454 & .429 & .172 & .794 & .959 & .282 & .000 & .000 & & .000 \\
\hline & $\mathrm{N}$ & 326 & 326 & 326 & 326 & 326 & 326 & 326 & 326 & 326 & 326 \\
\hline \multirow{3}{*}{ Gossip } & $\begin{array}{c}\text { Pearson } \\
\text { Correlation }\end{array}$ & -.043 & .051 & .080 & .018 & -.002 & -.062 & $.969^{* *}$ & $.943^{* *}$ & $.991^{* *}$ & 1 \\
\hline & $\begin{array}{l}\text { Sig. (2- } \\
\text { tailed) }\end{array}$ & .435 & .354 & .149 & .753 & .966 & .267 & .000 & .000 & .000 & \\
\hline & $\mathrm{N}$ & 326 & 326 & 326 & 326 & 326 & 326 & 326 & 326 & 326 & 326 \\
\hline
\end{tabular}

According to findings in table 39, the study found no significant correlation between social correlates and deviance behavior among teachers. Work load and teacher absenteeism $(\mathrm{r}=-0.040, \mathrm{p}>0.05)$, negligence $(\mathrm{r}=-0.020, \mathrm{p}>0.05)$, sabotage $(\mathrm{r}=-0.042, \mathrm{p}>0.05)$, gossip $(\mathrm{r}=-0.043, \mathrm{p}>0.05)$. Responsibility and teacher absenteeism ( $\mathrm{r}=.049, \mathrm{p}>0.05)$, negligence $(\mathrm{r}=$ $0.072, \mathrm{p}>0.05)$, sabotage $(\mathrm{r}=0.44, \mathrm{p}>0.05)$, gossip $(\mathrm{r}=0.051$, $\mathrm{p}>0.05)$. Leadership relations and teacher absenteeism $(r=0.90, p>0.05)$, negligence $(r=0.097, p>0.05)$, sabotage $(r=$ $0.076, \mathrm{p}>0.05)$, gossip $(\mathrm{r}=0.0180, \mathrm{p}>0.05)$. Administration support and teacher absenteeism $(\mathrm{r}=0.012, \mathrm{p}>0.05)$, negligence $(r=0.025, p>0.05)$, sabotage $(r=0.015, p>0.05)$, gossip $(\mathrm{r}=-0.018, \mathrm{p}>0.05)$. Policies and teacher absenteeism $(\mathrm{r}=-0.009, \mathrm{p}>0.05)$, negligence $(\mathrm{r}=0.041, \mathrm{p}>0.05)$, sabotage $(\mathrm{r}=0.003, \mathrm{p}>0.05)$, gossip $(\mathrm{r}=-0.002, \mathrm{p}>0.05)$. Physical facilities and teacher absenteeism ( $\mathrm{r}=-0.067, \mathrm{p}>0.05)$, negligence $(r=-0.035, \mathrm{p}>0.05)$, sabotage $(r=-0.060, \mathrm{p}>0.05)$, gossip $(r=-0.062, p>0.05)$. The results on social factors do not influence deviance among teachers. This implies that deviance among teachers could be stemming from other environmental issues that do not necessarily relate to the social or intrinsic factors.

\section{DISCUSSION}

Tour findings on social correlates agree with Anastasiou and Papakonstantinou (2015) study findingson factors affecting job satisfaction, stress and work performance of secondary education in Epirus, North West Greece. The study found out that secondary school teachers were not supported by the government, were not informed of changes on the curriculum resulting to unmet demands which caused stress and were seen to be deviant. Similarly, Adoeti, Shamsudin and Wan (2017) found that organizational leadership norms were deviant and were directed to the colleagues and learners. Such deviant acts included humiliating, silent treatment, raising voice at learners, withholding of official information from colleagues, theft from co-workers, assigning blames to colleagues, gossip and sexual harassment. This lead to lower level of self-confidence, commitment to the organization, increased absenteeism, quitting wok or intention to quit, and increased on-the-job drug use.

Travers and Cooper's (1997) study among teachers in Britain and France, workload and long working hours emerged as particular issues for English teachers as opposed to colleagues in France corroborated the findings of this study. The workplace deviant behavior was found to be related to stress factors at the work place. Further, in support of these findings, Fischer (2011) noted that the British teachers who were involved in the researcher cited work overload, poor working conditions and meagre pay as some of the sources of stress which in turn resulted in deviant behaviour among the teachers.

Igbe, Okpa and Aniah (2017) found that there was a positive significant relationship between non-payment of allowances, poor worker safety and deviant behavior among employees in University of Calabar, Cross River State, Nigeria The lack of payment of allowance left employees with external economic pressure. Hence, making the employees to engage in criminal tendencies such as; corruption, huge debts and borrowing learners' money in exchange for exams. This was also replicated by Koech, Tikoko and Chemwei (2014) who found that majority of teachers had stress brought about by several factors such lack of career advancement, unfavorable working conditions and low remuneration hence the teachers lack motivation from the system. It also found that poor relationship between the principal, lack of development opportunities and lack of school commitment, tension and negative emotions among the teachers resulted into stress and as a result deviant behavior.

Our results on deviance among teachers agree with Bennet, Marasi and Locklear (2018) who noted that employees who disrupt the organizational operations for personal purpose of the saboteur by creating unfavorable publicity embarrassment and harm the relationship with others. Similarly, Khan (2017) Khan carried out analysis on teachers' deviant behavior and its impact on students' academic performance in university of Peshawar and found that the level of teachers' deviant behavior was above average. This was confirmed by respondents who indicated that teachers showed favoritism, wasted time during teaching, took longer breaks, used verbal abuse, did not follow the course content as well as provoking students' against other teachers.

A study by Ünal (2012) in Konya province Turkey had similar findings where it was established that teachers repeated 24 types of deviant behavior for a total of 131 incidents. Further, the study found that nearly all the deviant behavior of teachers have a significant impact in flaunting rules or affecting interpersonal relationships within the school. 
Unlike the studies conducted by Ünal (2012) and Khan (2017) which agreed with this study findings which showed that teachers deviance behaviors was above average, a study by Coşkun and Balci (2020) had contradicting findings. Coşkun and Balci (2020) used causal comparative and correlational method study to examine teacherse" workplace aggression behaviours and organizational justice perceptions. Coşkun and Balci study findings revealed that teachers rarely observe aggressive behaviors at school.

Similarly, a study by Aksu (2016) reported contrary findings. Aksu (2016) study was carried out determine the level of teachers' organizational deviant behavior among teachers in Anatolian High Schools in İzmir. Aksu (2016) study found that teachers displayed organizational deviant behavior which were at low level. In addition, Köse (2013) survey study which investigated middle school teachers' perception of deviant behavior and its relation to administrators' strategic leadership skills had findings which were in contrary with this study findings. Köse (2013) study found that teachers' perceptions of deviance in their schools were at "seldom" level.

In another study, Azim, Hassan, Zaid and Daud (2020) examined the influence of supervisor support and organizational trust on workplace deviant behavior where results indicated that supervisory support and organizational trust influence workplace deviant behavior. Similarly, Adeoti, Shamsudin and Mohammad (2021) disagreed with these study findings. They investigated whether Opportunity and job pressure influenced deviant workplace behavior and results indicated that opportunity and job pressure significantly affected workplace deviance. Further, the study found that there was negative relationship between ethical climate and interpersonal deviance. However, with respect to workload, work pressure and interpersonal deviance, a positive relationship was found between the two variables.

\section{REFERNCES}

[1] Adeoti, M.O., Shamsudin, F.M. \& Mohammad, A.M. (2021), "Opportunity, job pressure and Deviant Workplace Behaviour: Does Neutralization Mediate The Relationship? A study of faculty members in public universities in Nigeria", European Journal of Management and Business Economics, 30 (2):170-190.

[2] Aksu, A. (2016). Organizational deviance and multi-factor leadership. Educational Research and abReviews, 11(8), 589-597.

[3] Anastasiou, S. \& Papakonstantinou, G. (2015). Factors Affecting Job Satisfaction, Stress And Work Performance of Secondary Education Teachers in Epirus, NW Greece. Int. J. of Management in Education. 8(1), 37 - 53.

[4] Azim, A. M. M., Hassan, M. S., Zaid, D. S., \& Daud, M. A. (2020). The Influence of

[5] Supervisor Support, Organizational Trust on Workplace Deviant Behavior: Do Psychological Contract Matter? International Journal of Academic Research in Business and Social Sciences, 10(2), 116-120.

[6] Bennett, R. J., Marasi, S., Locklear, L. (2018). Workplace Deviance, In: Oxford Research Encyclopedia of Business and Management. Oxford University Press, USA

[7] Bennett, R.J., Robinson, S.L., (2000). Development of a measure of workplace deviance. Journal of Applied Psychology 85 (1), 349-360.
[8] Bhui, K., Dinos, S., Galant-Miecznikowska, M., de Jongh, B., \& Stansfeld, S. (2016).

[9] Perceptions of work stress causes and effective interventions in employees working in public, private and non-governmental organisations: a qualitative study. BJPsych bulletin, 40(6), 318325.

[10] Coşkun, B. \& Balci, A. (2020). Teachers' Workplace Aggression Behaviors and Their Relationship with Organizational Justice. MANAS Journal of Social Studies9(3), 1391-1409.

[11] Fagbenro, D.A., \& Olasupo, O. M. (2020). Quality of Family Life and Workplace Deviant Behaviour with Perceived Competence as a Mediator among University Staff. Nǎ̌e gospodarstvo/Our Economy, 66(2), 15-27.

[12] Fischer, C. F. (2011).Supervisionofinstructionhttp://www.stanswartz.com/adm.tx t/chap .htm retrieved 20th march 2016

[13] Howald, N. Lortie, B. Gallagher, C., \& Albert, M. A., (2018). Preventing and Deterring

[14] Organizational Deviance. A White Paper prepared by the Visibility Committee of the Society for Industrial and Organizational Psychology.

[15] Igbe, J. E. Okpa, J. T., \& Aniah, E. A. (2017). Working conditions and deviant behaviour of employees in the University of Calabar, Cross River State, Nigeria. IOSR Journal of Humanities and Social Science (IOSR-JHSS)(22) 7, 74-83.

[16] Kagwe, M., Ngigi S and Mutisya S.(2018). Sources of Occupational Stress and Coping

[17] Strategies among Teachers in Borstal Institutions in Kenya. Edelweiss Psyi Open Access 2 (1): 18-21

[18] Khan, P. (2017). An Analysis of Teachers' Deviant Behavior and its Impact on Students'Academic Performance. FWU Journal of Social Sciences, Winter, 11 (2), 139-148

[19] Khan, S. A., Mahmood, A. \& Kanwal, S. (2015). How Perceived Supervisor Support Effects Workplace Deviance? Mediating Role of Perceived Organizational Support. Pakistan Journal of Commerce and Social Sciences, 9 (3), 940-967.

[20] Koech, S.J., Tikoko, B.J., \& Chemwei, B. (2014).Institutional factors that influence teachers' turnover in public secondary schools in Baringo County, Kenya. International Journal of Education and Research,2(3), 20-39.

[21] Köse, G.S. (2013). Ortaokul öÄŸretmenlerinin örgütsel sapma ve stratejik liderlik

[22] aras $\ddot{A ̈} \pm$ ndaki iliÅŸki üzerine alg $\ddot{A} \pm \operatorname{lar} \ddot{A} \pm$ : $\ddot{A}^{\circ}$ zmir ili örneÄŸi,

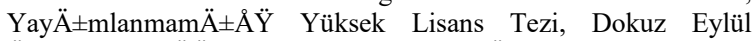
Üniversitesi, EÄŸitim Bilimleri Enstitüsü, $\ddot{A}^{\circ}$ zmir.

[23] Lawrence, T.B., \& Robinson. S.L. (2007). Workplace Deviance as Organizational Resistance. Journal of Management, 33(3), 378394.

[24] Muiga, W.F., Ombui, D., \& Iravo, D.M. (2016). Effects of WorkRelated Stress on Teachers "Performance in Public Secondary Schools in Kikuyu Sub County, Kenya.

[25] Ndung'u, G. W. (2017). Teacher Indiscipline and the Effectiveness of Disciplinary Measures Employed By Head teachers In Public Secondary Schools In Githunguri, Kiambu County, Kenya. Published Master of Education Research Project. Kenyatta University Repository.

[26] Palomo, M., Beinart, H., \& Cooper, M. J. (2010). Development and validation of the Supervisory Relationship Questionnaire (SRQ) in UK trainee clinical psychologists. British Journal of Clinical Psychology 49 (1): 131-149

[27] Peterson, D. K. (2002). Deviant workplace behavior and the organization's ethical climate. Journal of Business and Psychology 17(1): 47-61.

[28] Salakhova, V. B., Bulgakov, A. V., Sokolovskaya, I. E., Khammatova, R. S. \& Mikhaylovsky, M. N. (2016). Substantive (Content-Related) Characteristics of Deviant Behavior as a Social and Psychological Phenomenon. International Journal of Environmental \& Science Education, 11 (17), 10609-10622

[29] Travers, C. J., \& Cooper, C. L. (1996). Teachers under pressure: Stress in the teaching profession. London: Routledge 
International Journal of Research and Innovation in Social Science (IJRISS) |Volume VI, Issue I, January 2022 |ISSN 2454-6186

[30] Ünal, A. (2012). Deviant Teacher Behaviors and Their Influence on School Rules and Interpersonal Relationships at School. Egitim Arastirmalari. Eurasian Journal of Educational Research, 49 (1), $1-20$.
[31] Uwannah, N. C. (2015). Absenteeism, favoritism, and tardiness as predictors of job deviance in academia: The Nigeria experience. Journal of Social Sciences and Humanities, 1(2), 75-81. 